\title{
MICROBIAL CONTAMINATION OF SAND FROM MAJOR BEACHES IN FORTALEZA, CEARÁ STATE, BRAZIL
}

\author{
Regine Helena Silva dos Fernandes Vieira ${ }^{1 *}$; Dália dos Prazeres Rodrigues²; Everardo A. Menezes $^{3}$; \\ Norma Suely de Santana Evangelista ${ }^{1}$; Eliane M.F. dos Reis ${ }^{2}$; Leopoldo Melo Barreto ${ }^{1}$; Flávia Araújo Gonçalves ${ }^{1}$
}

${ }^{1}$ Instituto de Ciências do Mar, Labomar, Universidade Federal do Ceará, Fortaleza, Ceará, Brasil. ${ }^{2}$ Fundação Oswaldo Cruz, Rio de Janeiro, Rio de Janeiro, Brasil. ${ }^{3}$ Departamento de Análises Clínicas, Universidade Federal do Ceará, Fortaleza, Ceará, Brasil

Submitted: March 13, 2000; Returned to authors for corrections: September 26, 2000; Approved: May 25, 2001

\begin{abstract}
The presence of faecal contamination and pathogenic microorganisms in samples of dry and wet sand collected from three major beaches in Fortaleza, Ceará State, Brazil: (Praia do Mucuripe, Praia do Futuro and Praia do Caça e Pesca), during the period of May 1999 to January 2000 was evaluated. Praia do Caça e Pesca had the highest incidence of $E$. coli in dry sand (56\%) followed by Praia do Mucuripe (28\%) and Praia do Futuro (16\%). In wet sand, results were 48\%, 28\% and 24\% for Praia do Caça e Pesca, Praia do Futuro and Praia do Mucuripe, respectively. Only two samples from Praia do Futuro, one from dry sand and another one from wet sand, were positive for Salmonella. V. parahaemolyticus was isolated from four samples from Praia do Caça e Pesca (two from dry-sand samples and two from wet-sand), one from Praia do Futuro (wet sand), and three and four from Praia do Mucuripe (wet and dry sand, respectively). Yeasts belonged to the Candida genus. Dry-sand samples presented higher yeast contaminations level than wet-sand ones. Praia do Futuro had the highest level of yeast contamination (41\%), followed by Praia do Caça e Pesca (33\%) and Praia do Mucuripe (26\%).
\end{abstract}

Key words: sand contamination, yeasts, faecal coliforms, Vibrio parahaemolyticus, Salmonella

\section{INTRODUCTION}

According to the last census, Fortaleza is the fifth largest Brazilian city in terms of population. The city has approximately 2.2 million inhabitants and c.a. $70 \%$ is served by sewage collection system. The sewage is discharged in the ocean through a marine interceptor of 3,300 m length, at $15 \mathrm{~m}$ depth, after a "primary" treatment consisting of grating, screening and decantation of the raw sewage. According to data collected in locus, only $8 \%$ of this material finds its way to adjacent beaches. However, this quantity is sufficient to contaminate these areas $(12,28,29)$.

Sandy beaches are regions of transition between the firm land and the sea, and as such they are subjected to significant influences from both ecosystems. These areas are exposed to sharp variations in the rates of sun exposure, immersion and submersion, rainfall and concentration of nutrients $(17,18)$.

Fortaleza is a busy tourist destination. Local beaches are not only the main attraction for visitors, but also for residents. It is therefore of a great public health concern that these areas are periodically evaluated in regard to their level of microbial contamination. The present work aimed to determine the microbiological quality of the sand of selected major beaches of Fortaleza. The evaluation focused on Salmonella, total and faecal coliforms, Vibrio parahaemolyticus and yeasts.

\section{MATERIALS AND METHODS}

Thirty samples of dry sand and thirty samples of wet sand were collected from three ocean beaches in Fortaleza (Praia do Futuro, Praia do Mucuripe and Praia do Caça e Pesca) between May 1999 and January 2000. Sampling was carried out on Mondays, in median regions of the beach.

Each sample consisted of $100 \mathrm{~g}$ of the surface sand collected at a maximum depth of $2 \mathrm{~cm}$ using a sterilised spatula. The material was transferred to a sterile container, transported to the laboratory and tested in less than 2 hours.

* Corresponding author. Mailing address: Av. da Abolição 3207. 60165-081, Fortaleza, CE, Brasil. Fax: (+5585) 242 83 55. E-mail: regine@labomar.ufc.br 
For trials for Salmonella, $25 \mathrm{~g}$ of sand was weighed into 225 $\mathrm{ml}$ of $1 \%$ Lactose broth. One $\mathrm{ml}$ of this mixture was added to Selenite F and Rappaport medium modified according to Hofer and Kauffmann Tetrathionate broth (27). After 24 hours of incubation at $37^{\circ} \mathrm{C}$, innocula were removed with a platinum loop and sown in Hektoen Agar and Holt Harris Teague Agar (Difco). Biochemical identification of typical colonies was made according to Costa and Hofer (3). The antigenic characterization was made through fast binding, employing somatic and flagellar antisera produced by the Department of Bacteriology of the Instituto Oswaldo Cruz, RJ, Brazil.

The ICMSF (8) methodology was adopted in the identification of faecal coliforms, and five colonies grown in EMB agar were taken for further identification. Yeasts were identified by the technique developed by Paula (16). The identification of Vibrio parahaemolyticus followed Twedt's procedure (26).

\section{RESULTS AND DISCUSSION}

In coastal areas, outbreaks of gastroenteritis, hepatitis, salmonellosis, viral illnesses and occurrence of dermatitis and mycosis during the summer have usually been associated with marine pollution. Recently these factors have also been correlated with the contamination of beach sands, resulting from wastes left by users and from solids deposited by the tides (13).

Among 92 strains isolated from selective media for Salmonella, only two were confirmed as Salmonella, both serotype agona. These originated from Praia do Futuro wet and dry sand samples taken in different days. According to Russ and Yanko (22) and Thomason et al. (25), the survival of bacteria in a particular ecosystem is affected by the amount of organic nutrients, the presence of competitive microbiota and physico-chemical factors. The presence of enteric bacteria in the sands of Praia do Futuro can be attributed to the high number of patrons of "Chico do Caranguejo" restaurant where a traditional crab dish is served. The crabs are caught in mangroves and held on the sands of Praia do Futuro prior to processing. It is known that many serotypes of Salmonella can survive for periods as long as several months when soil conditions are suitable. These conditions refer mainly to temperature, exposure to sunlight, humidity, $\mathrm{pH}$ and the presence of organic matter (20).

Although Sanchez et al. (24) were able to isolate Salmonella from seawater collected in São Paulo State, Brazil, these authors were not successful in attempts to isolate this enteric bacterium from the sand. On the other hand, Rodrigues et al. (21) found Salmonella in the water from beaches of Rio de Janeiro, from the inward to the outer area of the Guanabara Bay. The authors identified the Salmonella agona serotype at Copacabana and Governador Island which supports the likelihood of the sandcontamination, a finding also confirmed in this work. According to those authors, this serotype is extremely common in the environment. Hofer and Costa (7) also identified this serotype in the sewage system of Niterói, Rio de Janeiro State.

We believe that the presence of this bacterium in wet sands of Praia do Futuro is associated with seawater contamination. The estuary of Cocó River, which flows through slums where houses are supported on stilts and the inhabitants' excreta are discharged directly into the river, is not very distant from the studied site. These untreated wastes are likely brought to adjacent beaches by a local marine current of an east-west coastal drift (15).

A total of 103 coliform colonies were isolated from the sixty samples analysed. Forty-six were confirmed as being E. coli, 53 Enterobacter and 4 Citrobacter.

The influence of marine currents on the contamination of sand has been proven once more when we analysed data from the remaining sampling sites. Contamination with Escherichia coli was detected in both wet- and dry-sand samples collected on all three beaches (Praia do Mucuripe, Praia do Futuro and Praia do Caça e Pesca).

The sands of Praia do Caça e Pesca contained the highest contamination with $E$. coli in both wet-sand and dry-sand samples (Table 1). This site is where the mouth of the estuary of the Cocó River is located. These data do not agree with those reported by Melo et al. (12), whose work on total and faecal coliforms on the beaches of Fortaleza showed lower values for this group in waters of Praia do Caça e Pesca. Since in the present work there was no quantification of the total and faecal coliforms, but only their identification, comparisons with Melo et al. (12) findings cannot be reliably made. In addition, seawater is toxic to coliforms due to its salinity (6). This was discussed by La Liberte and Grimes (10) who demonstrated that the extensive survival of E. coli in sediments can be attributed to fine particles in the soil and the high amount of organic material.

Vibrio parahaemolyticus is another bacterium isolated from the investigated sands. The numbers determined were very small. While many strains of Vibrionaceae were isolated (112), Table 1 shows that the presence of $V$. parahaemolyticus was confirmed in only two wet-sand samples (Mucuripe) and in three dry-sand samples (Mucuripe (2), and Caça e Pesca (1)). Vibrio parahaemolyticus is a marine bacterium that requires salt and organic matter to survive. According to Sakazaki et al. (23), in the case of contaminated food, the ingestion of at least $10^{6}$ cells is necessary for the process of gastroenteritis to take place, thus sand should not be a reason for concern. However, infection of open skin wounds would be, since Johnson et al. (9) reported a case of infection in the nail of the thumb of a patient who was hurt when opening oysters. Cells of V. parahaemolyticus were isolated from this wound.

Castrillón et al. (2) reported that yeasts are associated with a variety of terrestrial and aquatic substrates. Sometimes they may belong to specialised habitats and can be considered as indicators of pollution and potential sources of contamination. Lacaz (11) states that the variety of yeasts found in the soil and in seawater 
Table 1. Occurrence of E. coli, Salmonella, V. parahaemolyticus and C. albicans in sand samples from three beaches in Fortaleza, CE (Mucuripe, Futuro and Caça e Pesca).

\begin{tabular}{cccccc}
\hline & & \multicolumn{3}{c}{ POSITIVITY } \\
\cline { 3 - 5 } Beaches & sand samples & $\begin{array}{c}\text { E. coli } \\
\mathrm{n}(\%)\end{array}$ & $\begin{array}{c}\text { Salmonella } \\
\mathrm{n}(\%)\end{array}$ & $\begin{array}{c}\text { V. parahaemolyticus } \\
\mathrm{n}(\%)\end{array}$ & $\begin{array}{c}\text { C. albicans } \\
\mathrm{n}(\%)\end{array}$ \\
\hline Mucuripe & 10 & $6(60.0)$ & & $2(20.0)$ & $1(10.0)$ \\
Dry sand & 10 & $4(40.0)$ & & $2(20.0)$ & $1(10.0)$ \\
Wet sand & & & & $4(40.0)$ \\
\hline Futuro & 10 & $3(30.0)$ & $1(10.0)$ & & \\
Dry sand & 10 & $4(40.0)$ & $1(10.0)$ & $1(10.0)$ & $1(10.0)$ \\
Wet sand & 10 & $8(80.0)$ & & & $1(10.0)$ \\
\hline Caça e Pesca & 10 & $6(60.0)$ & & 5 & 8 \\
Dry sand & 60 & 31 & 2 & & \\
Wet sand & & & & & \\
\hline Total & & & & & \\
\hline
\end{tabular}

plays an important role in the medical pathology, causing cutaneous mycosis. Correspondingly, many mycosis cases related to beach environments could be directly linked to fungal microbiota. In the samples from the three beaches, the isolated yeast species belonged to the genus Candida: $C$. tropicalis, $C$. pseudotropicalis, C. albicans, C. glabata, C. stellatoidea, $C$. parapsilosis and C. krusei.

Of the collections conducted on three beaches, Praia do Futuro was the one that showed the highest percentage of isolated yeasts (41.03\%), followed by Praia do Caça e Pesca (33.33\%) and Praia do Mucuripe (25.64\%). Higher amounts were isolated from dry sands than from wet sands. The yeast Candida albicans, the most frequent one in the samples, is considered important in public health since it is significantly more virulent than the other species of Candida (19).

Menezes et al. (14) investigated the occurrence of yeasts in seawater, and in dry and wet beach sands of the city of Fortaleza. They isolated seven genera of the following microorganisms: Candida, Malassezia, Trichosporium, Rhodotorula, Torulopsis, Pichia and Hansenula. The most frequently isolated genus in all samples was Candida.

Sanchez et al. (24) also isolated C. albicans in 32 of 171 samples of sand collected from some beaches in São Paulo. Candida albicans is an opportunist pathogen and has been associated with a wide variety of oral, vaginal and cutaneous infections in humans $(4,5)$. Sanchez et al. (24) stressed the need of sanitary quality standards for sand of beaches for recreational use.

According to Vieira et al. (28), sea pollution results in an increased risk in the recreational use of beautiful beaches since it represents a threat for swimmers, surfers and for the people who depend on ocean resources.

Data in this study (Tables 1 and 2) characterized polluted beaches as those with faecal matter harmful to the swimmers, and mainly to children who play on beach sands. They run the highest risk of contracting illnesses caused by bacteria and yeasts. Burton et al. (1) established considerably higher levels of pathogens in sea sediments than in seawater which amplifies the public health risks since this contamination can persist for a long time.

\section{RESUMO}

\section{Contaminação microbiológica da areia de algumas praias de Fortaleza,Ceará, Brasil}

No presente trabalho, avaliou-se a presença de contaminação fecal e de microrganismos patogênicos em areia seca e areia úmida de três praias de Fortaleza, Ceará: Praia do Mucuripe, Praia do Futuro e Praia do Caça e Pesca. A praia que apresentou maior índice de contaminação com E.coli em areia seca foi a do Caça e Pesca (56\%), seguido das praias do Mucuripe (28\%) e Futuro (16\%). Em areia úmida a ordem decrescente de contaminação por E. coli foi Praia da Caça e Pesca, Futuro e Mucuripe com $48 \%$, $28 \%$ e $24 \%$ de contaminação, respectivamente. Salmonella foi isolada de duas amostras da Praia do Futuro, uma de areia seca e outra de areia úmida. V. parahaemolyticus foi isolado em 2 amostras de areia seca e 2 de úmida da Praia da Caça e Pesca. Esse patógeno foi isolado de uma amostra de areia úmida da Praia do Futuro e de três de areia úmida e quatro de areia seca da Praia do Mucuripe. As leveduras encontradas em todas as amostras pertenciam ao gênero Candida. $\mathrm{O}$ índice de contaminação por leveduras foi maior em amostras de areia seca que de areia úmida. A praia que apresentou maior contaminação por leveduras foi a Praia do Futuro (41\%), seguida da Praia do Caça e Pesca e (33\%) e da Praia do Mucuripe (26\%).

Palavras-chave: contaminação de areia, leveduras, coliformes fecais, Vibrio parahaemolyticus, Salmonella 


\section{REFERENCES}

1. Burton, J.R.; Gunnison, D.; Lanza, G.R. Survival of pathogenic bacteria in various freshwater sediments. Appl. Environ. Microbiol., 53:633638, 1987.

2. Castrillón, A.L.; Gambale, W.; Corrêa, B. Leveduras isoladas de águas do Rio Solimões e do Rio Tarumá-Mirim (Negro). Estudo preliminar. Rev. Microbiol., 22:102, 1991.

3. Costa, G.A.; Hofer, E. Isolamento e identificação de Enterobactérias. Instituto. Oswaldo Cruz, Rio de Janeiro, 1972, 120p.

4. Emmons, C.W.; Binford, C.H.; Utz, J.P.; Kwan-Chung, K.J. Medical Mycology. Lea \& Febiger, Philadelphia, PA, 1977, 592p.

5. Gentiles, J.C.; La Touche, C.J. Yeasts as human and animal pathogens. In: Rose, A.H.; J.S. Harrison (eds.), The yeasts. Academic Press, London, 1969, p.107-182.

6. Hagler, A.N.; Hagler, L.C.S.M. Indicadores microbiológicos de qualidade sanitária. In: Roitman, I.; Travassos, L.R.; Azevedo, J.L. (eds.), Tratado de Microbiologia, Manole, São Paulo. 1988, p.85-102.

7. Hofer, E.; Costa, G.A. Investigação sobre a ocorrência de Salmonella em esgotos sanitários da cidade do Rio de Janeiro. Mem. Inst. Oswaldo Cruz, 70:221-236, 1972.

8. ICMSF-International Commission on Microbiological Specifications for Foods. Microorganisms in Foods: 1. Their significance and methods of enumeration. University of Toronto Press, Toronto, 1978, p.131139.

9. Johnson, D.E.; Weinberg, J.; Ciarkowski, P.; West, P.; Colwell, R.R. Wound infection caused by Kanagawa negative Vibrio parahaemolyticus. J. Scien. Microbiol., 20:811-812, 1984.

10. La Liberte, P.; Grimes, D.J. Survival of Escherichia coli in lake bottom sediments. Appl. Environ. Microbiol., 43:623-628, 1982.

11. Lacaz, C.S. Micologia Médica. Savier, São Paulo. 1991, 695p.

12. Melo, M.T.D.; Vieira, R.H.S.F.; Saker-Sampaio, S.; Hofer, E. Coliforms and Salmonella in seawater near to domestic sewage in Fortaleza (Ceará, Brazil). Microbiol. SEM, 13:463-470, 1997.

13. Mendes, B.; Nascimento, M.J.; Oliveira, J.S. Preliminary characterisation and proposal of microbiological quality standard for sand beaches. Wat. Sci Tech. 27:453-456, 1993.

14. Menezes, E.A.; Trindade, E.C.P.M. Contribuição ao estudo das leveduras em praias da cidade de Fortaleza - Ceará. V ENAMA, Fortaleza, 1996, p.34.

15. Morais, J.O. Processos de assoreamento do Porto do Mucuripe. Arq. Ciên. Mar, 12:139-149, 1972.
16. Paula, C.R. Contribuição ao estudo das leveduras em praias da Baixada Santista. São Paulo, 1978 (Mestrado, Dissertação. Instituto de Ciências Biomédicas, USP, São Paulo, Brazil).

17. Rheinheimer, G. Marine Mikrobiologie. In: Jahresbericht Institut für Meereskunde Kiel, Germany, 1969, p.55-59.

18. Rheinheimer, G. Bakteriologisch- öekologische untersuchungen an sandstränden an Nord-und Ostsee. Botanica Marina, 20: 385-399, 1977.

19. Rippon, J.W. Candidiasis and the pathogenic yeast. In: Saunders, W.B. Medical Mycology, Philadelphia, PA, 1988, p.532-575.

20. Rodrigues, D.P.; Ribeiro, R.V.; Hofer, E. Enterobactérias patogênicas no solo de áreas de recreação da cidade do Rio de Janeiro, RJ. R . Bras. Med. Vet., 16(6):256-259, 1994.

21. Rodrigues, D.P.; Solari, C.A.; Ribeiro, R.V.; Costa, J.E.C.M.; Reis, E.M.F.; Silva-Filho, S.J.; Hofer, E.- Salmonella em águas de praias do município do Rio de Janeiro, RJ. Rev. Microbiol., 20:12-17, 1989.

22. Russ, C.F.; Yanko, W.A. Factors affecting Salmonellae repopulation in composted sludges. Appl. Environ. Microbiol., 41:597-602, 1981.

23. Sakazaki, R.; Tamura, K.; Kato, T.; Obara, Y.; Yamai, S.; Hobo, K. Studies on the enteropathogenic, facultatively halophilic bacteria, Vibrio parahaemolyticus. III. Enteropathogenicity. Jpn. J. Med. Sci. Biol., 21:325-331, 1968.

24. Sanchez, P.S.; Agudo, E.G. Castro, F.G. Alves, M.N. \& Martins, M.T. Evaluation of the sanitary quality of marine recreational waters and sands from beaches of the São Paulo State, Brazil. Wat. Sci. Tech. 18:61-72, 1986

25. Thomason, B.M.; Dodd, D.J.; Cherry, W.B. Increased recovery of Salmonella from environmental samples enriched with buffered peptone water. Appl. Environ. Microbiol. 34(3):270-273, 1977.

26. Twedt, R.M. Recovery of Vibrio parahaemolyticus and related halophilic vibrios. Bacteriological analytical manual, $6^{\text {th }} \mathrm{ed}$. Association of Official Analytical Chemists, Arlington, VA, 1984, p. $1-8$.

27. Van Schothorst, M.; Leusden, F.M.; Jeunink, J.; Dreu, J. Studies on the multiplication of Salmonella in various enrichment media at different incubation temperatures. J. Appl. Bacteriol. 42:157-163, 1977.

28. Vieira, R.H.S.F.; Rodrigues, D.P.; Evangelista, N.S.S.; Theophilo, G.N.D.; Reis, E.M. F. Colimetry of marine waters off Fortaleza (Ceará State, Brazil) and detection of enteropathogenic Escherichia coli strains. Internatl. Microbiol., 1:221-224,1998.

29. Vieira, R.H.S.F.; Silva, P.R.F.G.; Lehugeur, L.G.; Sousa, O.V. Colimetria da água da praia da Barra do Ceará, Fortaleza, Ceará. Arq. Ciên. Mar., 32:119-122, 1999 . 